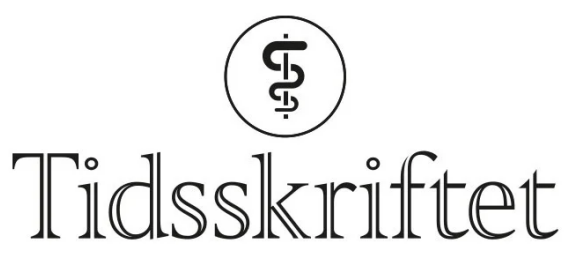

DEN NORSKE LEGEFORENING

\title{
Kortfattet om behandling av søvnlidelser
}

\author{
ANMELDELSER
}

\section{NIKOLAJ KAHN}

Psykologspesialist, St Olav Hospital - Østmarka - Enhet for psykisk helse i somatikken

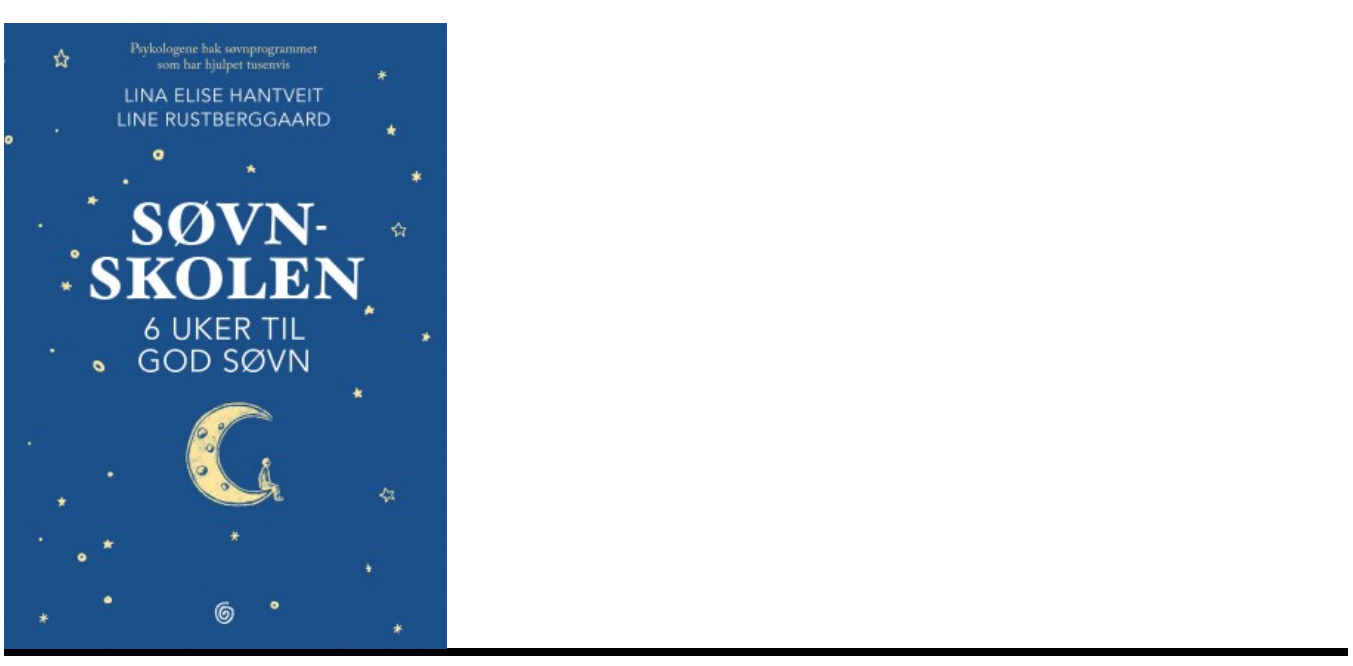

Lina Elise Hantveit, Line Rustberggaard

Søvnskolen

6 uker til god søvn. 134 s. Oslo: Kagge Forlag, 2020. Pris NOK 379

ISBN 978-82-48-92525-5

Søvnvansker er et av de vanligste problemene vi møter i helsevesenet, nærmest uavhengig av spesialitet. I Søvnskolen av psykologene Lina Elise Hantveit og Line Rustberggaard blir leseren presentert for behandlingsmetoden mot ikke-organisk insomni, nemlig Kognitiv adferdsterapi for insomni (CBT-i).

Boken henvender seg direkte til mennesker med søvnvansker. Den språklige formen er konsekvent i du-form, og språket er tilpasset slik at det ikke blir for teknisk. Formatet på boken ligger tett opp til selvhjelpslitteratur, der forfatterne på en enkel og lettfattelig måte går gjennom hvordan man definerer søvnvansker, hva behandlingen består i og hva som kreves av dem som skal gå gjennom behandlingen. Det gis en kort fremstilling av forenklet 
søvnteori, i tillegg til at boken tar opp viktige tema som motivasjon for endring, hvordan håndtere manglende respons på behandlingen og ikke minst når man ikke skal gjennomføre behandlingen. Det er tydelig at målet er å gjøre en ikke-medikamentell og effektiv behandlingsform mer tilgjengelig for befolkningen.

For de fleste leserne kan boken være et viktig supplement til helsehjelpen for pasienter med søvnlidelser. Forfatterne formidler godt hvordan man praktisk går frem for å bedre sitt søvnmønster, og de tar opp kjente kliniske problemstillinger, som uhensiktsmessig søvnadferd og psykologiske aspekter ved dårlig søvn.

Dessverre blir den teoretiske gjennomgangen av den såkalte toprosessteorien for utydelig og uforståelig. Dette er en behandlingsform som har et svært tydelig og godt faglig forankret behandlingsrasjonale, der god psykoedukasjon er sentral for å sikre at pasientene faktisk gjennomfører behandlingen. Jeg savner også mer omtale av hvilke søvnvansker denne metoden ikke egner seg for (de med organiske forstyrrelser i søvn-våkenhetsrytmen, obstruktiv søvnapné og andre organiske søvnlidelser).

Det er videre et problem at underoverskriften på forsiden omtaler forfatterne som «Psykologene bak søvnprogrammet som har hjulpet tusenvis». Dette kan misforstås dithen at det er forfatterne som har funnet opp metoden. Riktignok har de sin søvnskole på Lovisenberg sykehus, men det er nok Colin Espie, Charles Morin mfl. som må krediteres for metoden.

Uansett, boken vil være et nyttig verktøy for den «vanlige pasient» med søvnvansker og supplerer den allerede eksisterende norske litteraturen om emnet.

Publisert: 12. oktober 2020. Tidsskr Nor Legeforen. DOI: 10.4045/tidsskr.20.o618

(C) Tidsskrift for Den norske legeforening 2023. Lastet ned fra tidsskriftet.no 26. april 2023. 